\title{
The Relationship Between Quality of Teacher Work Life and Turnover Intention
}

\author{
Umi Anugerah Izzati, Olievia Prabandini Mulyana \\ Department of Psychology \\ Universitas Negeri Surabaya \\ Surabaya, Indonesia \\ umianugerah@unesa.ac.id
}

\begin{abstract}
This study aims to determine the relationship between quality of work life and turnover intention of teachers. The subjects of this study were teachers who worked at one of the private vocational high schools. This research method uses quantitative methods. The research instrument used was the scale of quality of work life and turnover intention scale. Data analysis in this study uses product moment correlation. The results of this study indicate there is a relationship between quality of work life and turnover intention. The relationship between variables is negative, meaning the higher the quality of work life, the lower the turnover intention of the teachers.
\end{abstract}

Keywords - quality of work life; turnover intention; teachers

\section{INTRODUCTION}

Every organization has certainly experienced a turnover of its employees. [1] states that turnover is the behavior of employees leaving the company and looking for opportunities to work at other companies. The intention to quit the job is known as turnover intention. Meanwhile [2] states the intention to stop working is the desire or desire to consciously and planned to leave an organization.

Turnover intentions refer to individual subjective estimates of the likelihood that individuals will leave the organization in the near future [3]. The turnover process occurs in employees through several stages according to [4] including the reduction in satisfaction; think out; intention to leave and find a new job; comparing new jobs and old jobs; decision to leave or stay. According to [5] employees who are not satisfied with work or other factors related to their work, will be able to reduce their commitment to an organization. Their dissatisfaction is generally always associated with problems of performance degradation which include slowness at work, high employee turnover rates and high absenteeism or absenteeism.

There are several factors that influence members of an organization have the intention to stop working according to [6] namely age, length of work, level of education, engagement with the organization, job satisfaction, and the culture where the individual works. Low employee satisfaction can be caused by the low quality of work life felt by employees. The quality of work life significantly influences employee satisfaction or dissatisfaction in their work [7]. Also links the intention to stop work with employee job satisfaction and the quality of work life with their organization. The low quality of work life of employees will indirectly result in high turnover intentions for employees.

Quality of work life refers to the pleasant or unpleasant working environment for the people involved in it [8]. Another understanding of the quality of work life is expressed by [9] which defines it as a set of phenomena and attributes that arise in the interaction of a person and the environment in which he works in an organization. Another opinion states that the quality of work life is the perception of employees regarding the welfare, atmosphere and experience of workers that refers to how effective the work environment [10].

According to [11] there are two ways of looking at the meaning of quality of work life. The first way is to equate quality of work life with a number of objective organizational conditions and practices. The second way is to equate Quality of Work life with employee perceptions about security in work, job satisfaction, and conditions for being able to grow and develop as humans.

Quality of work life can also be interpreted as employee perceptions based on employee experience at work, which is obtained from the company's response to the needs and welfare of employees [12]. According to [13] the quality of work life is defined as an employee's assessment of the state of all aspects of life in the workplace which includes compensation, opportunities to participate and progress, job security, type of work, organizational characteristics, and quality of interaction between members of the organization.

Several studies that have been carried out previously relating to the relationship between quality of work life and intentions of moving work include [14]; [15]; [16]; [17]. The results of the study showed that there was a negative relationship between the quality of work life and turnover intention. None of the previous studies have used the educational organization settings especially schools and none have used teacher subjects especially private vocational high school teachers.

Based on a preliminary study through interviews conducted with the vice-principal and several teachers in one private vocational high school showed that many teachers continue to work at the school without having the intention to transfer to another school. This is also shown from the number of years 
that teachers have over 5 years. They also showed a desire to develop their potential to support the teaching process. This reality shows that teachers in vocational high schools have low turnover intention. The existence of this phenomenon is interesting to be a research topic because teachers who work in private vocational high schools get salaries that are not as high as those of public vocational high school teachers, but these conditions still make these teachers survive to work in their schools.

Based on the above phenomenon, researchers are interested in examining the relationship between quality of work life and turnover intention in private vocational high school teachers.

\section{METHOD}

This research uses a quantitative method approach. Quantitative research emphasizes its analysis on numerical data that is processed by statistical methods [18]. Correlational descriptive research design was used in this study to determine the relationship between quality of work life with turnover intention in vocational high school teachers.

This research is population research. Research subjects are teachers who work in one private vocational high school. The number of subjects in this study were 60 teachers.

Measuring instruments used in this study are the scale of work life quality and turnover intention scale. The scaling model used is a Likert scale model. The responses for the two instruments above use the Likert scale. The validity test used in this study was conducted by correlating the scores at each atem with the total score (corrected item-total correlation). The limit used in this study is $r>0.30$. While the reliability test using Cronbach alpha data analysis techniques with the help of SPSS version 21.0 for Windows.

The quality of work life scale in this study was based on theory [12] to measure teachers' perceptions based on their experience in the workplace. On the scale of quality of work life there is a validity coefficient that moves between 0.375 0603 and the reliability coefficient of 0.885 .

The turnover intention scale in this study was made based on theory [19] to measure individual subjective estimates of the likelihood that individuals will leave the organization in the near future. On the scale of turnover intention the validity coefficient in this study moves between $0.302-0.725$ and the reliability coefficient is 0.860 .

The data analysis technique used to test the hypotheses in this study is the product moment correlation technique, because the technique can be used to determine the relationship between the two variables studied. Hypothesis testing used in this study was carried out with the help of SPSS version 21.0 for windows. Before using product moment correlation techniques, research data must meet basic assumptions. The assumption test consists of the normality test and the linearity test. Normality test in this study aims to determine whether the data obtained are normally distributed or not normally distributed. Data normality was tested using the Kolomogorov-Smirnov Test with the help of SPSS version 21.0 for windows. Then a linearity test is conducted in this study which aims to determine whether the research data is linear or not. Data linearity in this study was tested using a test of linearity with a significance level of 0.05 with the help of SPSS version 21.0 for windows. If the research data is proven to meet basic assumptions, then a hypothesis test is conducted using the product moment correlation technique using SPSS version 21.0 for windows.

\section{RESULTS AND DISCUSSION}

The results of the normality and homogeneity test are prerequisite tests before testing the hypothesis. The first normality test is done to see the deviation of the research results from the hypothetical frequency. If there are no deviations, the tested variable has a normal distribution. The normality test using the Kolomogorov-Smirnov technique shows $p>0.05$ which means the distribution of data on the quality of work life and turnover intention is normal. Hemogeneity test based on the Levene's test shows $p>0.05$ meaning that the distribution of quality of work life and turnover intention has a homogeneous variant or the data comes from populations with the same variant. After the prerequisite or assumption tests are conducted and the results are met, the next step can be to use parametric data analysis.

Hypothesis testing uses product moment correlation analysis with the help of SPSS version 21.0 for windows, to prove the relationship between quality of work life and turnover intention. The results of the product moment analysis $(\mathrm{r}=-0.670, \mathrm{p}<0.05)$ indicate that it is significant. Thus, the research hypothesis which states that there is a relationship between quality of work life and turnover intention in vocational high school teachers, is accepted. The correlation coefficient of -0.670 indicates the direction of the relationship in this study is negative, meaning that the higher the quality of work life, the lower the level of turnover intention on the teacher.

The results of this study are also supported by research conducted by states that there is a significant negative relationship between the quality of work life with the intention of turnover where the more positive the quality of work life, the lower the intense turnover and vice versa. The quality of work life on human resources is good, it will have a positive impact on the company, such as reducing absenteeism and turnover.

According to [19] mentioned several factors that cause turnover intention include individual characteristics and work environment. The work environment can include the physical and social environment. The physical environment includes conditions of temperature, weather, construction, buildings, and location of work. While the social environment includes socio-culture in the work environment, and the quality of work life.

Quality of work life helps increase employee loyalty to his organization and decreases their desire to leave the company. Vocational high school teachers in this study have a high quality of work life making them loyal to the educational organization where they work so that the desire to quit their job is classified as low. 


\section{CONCLUSION}

This study concluded that quality of work life has relationship on turnover intention of teachers in vocational High School. Teachers who have high quality of worklife will have low turnover intention.

This study has limitations that only a limited number of subjects from one of vocational high school teachers. Furthermore, greater number of subject teachers in various vocational high schools. In addition, this study put less attention to other variables that can influence the turnover intention.

\section{REFERENCES}

[1] Handoko, T. H. (2008). Manajemen Personalia \& Sumberdaya Manusia. Yogyakarta: BPFE-Yogyakarta

[2] M. Hofaidhllaoui dan N. Chhinzer (2014). The relationship between satisfaction and turnover intentions for knowledge workers. Engineering Management Journal. Vol 26 (2): 3-9.

[3] Mobley, W.H. (1982) Employee Turnover: Causes, Consequences, and Control. Reading, MA: Addison-Wesley.

[4] Abelson, M.A. (1986) Startegic Management of Turnover : a model for the helath service administrator, Health Care Manage Review, Vol.11 (2), pp 61-7.

[5] Robbins. Perilaku Organisasi, Jakarta : Indek Group Gramedia.

[6] Ridlo. L.A (2012). Turnover karyawan "kajian literatur". Surabaya: PH Movement Publication.

[7] F. Muindi, P. K. Obonyo. Quality of Work Life, Personality, Job Satisfaction, Competence, and Job Performance: A Critical Review of Literature European Scientific Journal. 11 (26): 223-240, 2015.
[8] Davis and Newstroom (2004). Perilaku dalam organisasi. Erlangga: Jakarta.

[9] L. Sojka. Specification of the Quality of Work Life Characteristics in the Slovak Economic Environment. Sociologia, 46(3), 283-299, 2014.

[10] Faghih, R. Mohsen and Ansari (2013). "Effect of Quality of Work Life on Organizational Commitment by SEM (Case Study: OICO Company)". International Journal of Academic Research In Business and Social Science. Vol. (3), No.10; pp.135-144.

[11] W. F. Cascio, Managing Human Resources. Productivity, Quality of Work Life, Profit. New York: McGraw Hill International. 2006.

[12] Walton, R.E (1975). Criteria for Quality of Working Life. In L.E. Davis \& A.B. Cherns (Eds.). Quality of Working Life, 1, New York: Free Press, pp. 91-104.

[13] Riggio, R. E. ( 2009). Introduction to Industrial/Organizational Psychology Fifth. Edition. New Jersey: Prentice Hall.

[14] Negara R.S.G and Nurtjahjanti H (2013). Hubungan antara kualitas kehidupan kerja dengan intensi turnover pada pilot penerbangan angkatan darat (PENERBAD) di Semarang dan Jakarta. Fakultas Psikologi Universitas Diponegoro.

[15] Almalki, M.J., Fitz Gerald, G., Clark, M. The Relationship between Quality of Work Life and Turnover Intention of Primary Health Care Nurses in Saudi Arabia. BMC Health Services Research, 12 (314), 2012.

[16] Celika, D.A. \& Oz, E.U (2011). The Effects of Emotional Dissonance and Quality of Work Life Perceptions on Absenteeism and Turnover Intentions among Turkish Call Center Employees, Procedia - Social and Behavioral Sciences, 30, pp. 2515-2519. 2011.

[17] Demir, M (2011). The Analysis of the Relationship among Emotional Intelligence, Organizational Deviance, Quality of Work Life and Turnover Intentions in Hospitality Business, European Journal of Tourism Research, 4(2), pp. 214-216.

[18] Azwar, (2009). Metode Penelitian. Yogyakarta: Pustaka Pelajar.

[19] Mobley, W. H (2011). Pergantian karyawan: sebab, akibat, dan pengendaliannya. Jakarta: PT. Pustaka Binama Pressindo. 2011. 